\title{
Virulence factors, serogroups and antimicrobial resistance properties of Escherichia coli strains in fermented dairy products
}

Farhad Safarpoor Dehkordi, Farshad Yazdani, Jalal Mozafari and Yousef Valizadeh

\begin{abstract}
Background: From a clinical perspective, it is essential to know the microbial safety of fermented dairy products. Doogh and kashk are fermented dairies. These products are used by millions of people but their microbial qualities are unknown. Shiga toxin producing Escherichia coli (STEC) is one of the most commonly detected pathogens in the cases of food poisoning and food-borne illnesses. The present investigation was carried out in order to study the molecular characterization and antimicrobial resistance properties of STEC strains isolated from fermented dairy products.

Methods: Six hundred fermented dairy samples were collected and immediately transferred to the laboratory. All samples were cultured immediately and those that were E. coli-positive were analyzed for the presence of O157, O26, O103, O111, O145, O45, O91, O113, O121 and O128 STEC serogroups, tetA, tetB, blaSHV, CITM, cmIA, cat1, aadA1, dfrA1, anr, aac (3)- $I V$, sul1 and ereA antibiotic resistance genes and stx1, stx2, eaeA, ehly, cnf1, cnf2, iutA, cdtB, papA, trat, sfaS and fyuA virulence factors using PCR. Antimicrobial susceptibility testing was performed also using disk diffusion methodology with Mueller-Hinton agar.

Results: Fifty out of 600 (8.33\%) dairy samples harbored E. coli. In addition, yoghurt was the most commonly contaminated dairy. O157 (26\%) and O26 (12\%) were the most commonly detected serogroups. A significant difference was found between the frequency of Attaching and Effacing E. coli and Enterohaemorrhagic E. coli $(P<0.05)$. Stx $1(44 \%)$, eae (36\%), papA (32\%) stx2 (30\%), and ehly (28\%) were the most commonly detected virulence factors. The genes encode resistance against tetracycline (tetA and tetB) $(76 \%$ and $70 \%$, respectively), cephalothin (blaSHV (38\%), ampicillin (CITM) (36\%) and gentamicin (aac (3)-IV) (32\%) were the most commonly detected. High resistance levels to tetracycline (84\%), penicillin (46\%), ampicillin (38\%) and streptomycin (36\%) were observed.

Conclusion: Fermented dairy products can easily become contaminated by antibiotic resistant STEC strains. Our findings should raise awareness about antibiotic resistance in Iran. Clinicians should exercise caution when prescribing antibiotics, especially in veterinary treatments.
\end{abstract}

Keywords: Shiga toxin-producing Escherichia coli, Virulence factors, Antibiotic resistance properties, Fermented dairy products, Iran

\section{Background}

Dairy products are raised as complete foods especially for juveniles. Their high value for proteins, minerals, fats and vitamins is undeniable. Doogh (also known as yoghurt drink) is a yogurt-based beverage which is popular in Iran and also found in Afghanistan, Azerbaijan, Armenia, Iraq,

\footnotetext{
*Correspondence: Dr.Farhads@yahoo.com
Young Researchers Club and Elite, ShahreKord Branch, Islamic Azad

* Correspondence: Dr.Farhads@yahoo.com
Young Researchers Club and Elite, ShahreKord Branch, Islamic Azad University, P.O. Box 166, ShahreKord, Iran
} Universty, P.O. Box 166, ShahreKord, Iran

() Biomed Central

(c) 2014 Dehkordi et al.; licensee BioMed Central Ltd. This is an Open Access article distributed under the terms of the Creative Commons Attribution License (http://creativecommons.org/licenses/by/2.0), which permits unrestricted use, distribution, and reproduction in any medium, provided the original work is properly credited. The Creative Commons Public Domain Dedication waiver (http://creativecommons.org/publicdomain/zero/1.0/) applies to the data made available in this article unless otherwise stated.

Syria, Turkey, Pakistan and Balkans. Kashk is a thick whitish liquid similar to whey, used in traditional Persian cooking. Kashk is a fermented dairy product manufactured traditionally in dried form and produced industrially in liquid form in Iran. Dried kashk is a concentrated yogurt-type product produced with dehydration of homemade yogurt by sun-drying in summer months by nomads and villagers in the different regions of Iran [1]. Doogh, yoghurt and kashk are rich in potassium, calcium, protein and group B vitamins. In a day, Millions of people use 
from these dairy products in their routine meal. Unfortunately, adequate heat and time were not performed in their traditionally producing.

Shiga toxin-producing Escherichia coli (STEC) is one of the most common milk-borne pathogens [2-4]. Infection with STEC strains can result in a spectrum of outcomes, ranging from asymptomatic carriage to uncomplicated diarrhea, bloody diarrhea, hemolytic uremic syndrome (HUS), thrombocytopenia, hemolytic anemia, and acute renal failure [5-8]. High mortality and morbidity rates have been reported for HUS, which can occur from infection with STEC strains $[5,9,10]$. The pathogenesis of $E$. coli is related to several bacterial virulence factors $[8,11,12]$. Some of the most important virulence factors in $E$. coli strains are the intimin (eae) protein, two phage-encoded cytotoxins called $s t x 1$ and $s t x 2$, the plasmid-encoded enterohemolysin or enterohaemorrhagic E. coli (EHEC) protein known as hemolysin $(e h l y)[8,11,12]$. The Cytotoxic Necrotizing Factor $(c n f)$ is another putative toxin which is responsible for induces enlargement and multinucleation of cultured eukaryotic cells [13]

A broad spectrum of Gram-negative bacterial species has been shown to produce Cytolethal Distending Toxin (CDT) [14], and three closely linked genes ( $c d t A, c d t B$, and $c d t C)$ are required for toxin expression [14].

Most outbreaks and sporadic cases of bloody and nonbloody diarrhea and HUS have been attributed to strains of the STEC serogroup O157 [15,16]. However, non-O157 strains such as O26, O103, O111, O145, O45, O91, O113, O121 and O128 have been shown to cause food poisoning, HUS, bloody diarrhea, and other gastrointestinal illnesses [2,15-17].

Diseases caused by E. coli often require antimicrobial therapy; however, antibiotic-resistant strains of this bacterium cause longer and more severe illnesses than their antibiotic-susceptible counterparts. Several studies have shown that antibiotic resistance in E. coli has increased over time [2,16,18-21]. In keeping with this, an epidemiological investigation in Iran revealed that STEC strains were the most commonly detected strains in patients with diarrhea and that there was a high incidence of resistance (85-100\%) to commonly used antibiotics [22-25].

There were no data on the distribution of serogroups, virulence genes and the antimicrobial resistance properties of E. coli strains isolated from yoghurt, kashk and doogh. Therefore, the aim of the present study was to characterize E. coli strains isolated from yoghurt, kashk and doogh at the molecule level and investigate their susceptibility to 14 commonly used antibiotics.

\section{Methods}

\section{Sampling and Escherichia coli identification}

Overall 600 dairy products including 200 yoghurt, 200 doogh and 200 kashk samples were purchased from supermarkets and retailers in various parts of Iran at summer of 2012. All of these dairy products were made traditionally by native people and after collection were kept under refrigeration in plastic bags. Samples were transported under refrigeration (at $4-6^{\circ} \mathrm{C}$ ) in thermal boxes containing ice packs. All samples were diluted in phosphate buffered saline (PBS, Merck, Germany). A 25 g portion of each sample was blended with $225 \mathrm{~mL}$ of nutrient broth (Merck, Germany) for $2 \mathrm{~min}$, using a Stomacher lab blender and incubated at $37^{\circ} \mathrm{C}$ for $24 \mathrm{~h}$. A $1 \mathrm{~mL}$ sample of the nutrient broth culture was mixed with $9 \mathrm{~mL}$ of MacConkey broth (Merck, Germany) and further incubated at $37^{\circ} \mathrm{C}$ for $24 \mathrm{~h}$. One loop of each tube was streaked on MacConkey agar (Merck, Germany). Such colonies were confirmed as E. coli using standard biochemical tests (e.g., Indole, Methyl red, Voges-Proskauer and Citrate utilization tests). Colonies were confirmed as $E$. coli by PCR [26]. E. coli isolates were stored in Tryptic Soy Broth (TSB, Merck, Germany) containing $20 \%$ glycerol at $-70^{\circ} \mathrm{C}$ for further characterization.

\section{Antimicrobial susceptibility testing}

Antimicrobial susceptibility testing of the isolates was performed using the Kirby-Bauer disc diffusion method and Mueller-Hinton agar (Merck, Germany) according to Clinical and Laboratory Standards Institute (CLSI) guidelines [27]. Inoculated plates were incubated aerobically at $37^{\circ} \mathrm{C}$ for $18-24 \mathrm{~h}$, after which antimicrobial susceptibility in the $E$. coli isolates were tested. Penicillin $(10 \mu \mathrm{g} /$ disk $)$, tetracycline $(30 \mu \mathrm{g} /$ disk $)$, streptomycin (10 $\mu \mathrm{g} /$ disk), chloramphenicol (30 $\mu \mathrm{g} /$ disk), sulfonamide (100 $\mu \mathrm{g} /$ disk), sulfamethoxazole $(25 \mu \mathrm{g} /$ disk $)$, gentamicin (10 $\mu \mathrm{g} /$ disk), cephalothin (30 $\mu \mathrm{g} /$ disk), trimethoprim (5 $\mu \mathrm{g} /$ disk), enrofloxacin (5 $\mu \mathrm{g} /$ disk), ciprofloxacin (5 $\mu \mathrm{g} /$ disk), ampicillin $(10 \mathrm{u} /$ disk $)$, and nitrofurantoin $(300 \mu \mathrm{g} /$ disk $)$ were tested. The results were interpreted in accordance with CLSI criteria [27]. E. coli ATCC 25922 was used as quality control for antimicrobial susceptibility determination.

\section{DNA extraction}

Bacterial strains were grown overnight in Trypticase Soy Agar (TSA, Merck, Germany) at $37^{\circ} \mathrm{C}$. A single colony was suspended in $100 \mu \mathrm{L}$ of sterile distilled water. After boiling the suspension for $13 \mathrm{~min}$, the suspension was frozen and centrifuged at 14,000 rpm for 15 min to pellet the cell debris [28]. The supernatant was used as a template for PCR amplification.

\section{PCR detection of serogroups, virulence factors and antibiotic resistance genes in STEC strains}

The PCR assays, specific primer sequences and the predicted size of the amplified products for the different pathogenic gene coding regions including, cnf1, cnf2, st $x 1$, stx 2 , 
Table 1 Primer sequence for detection of STEC serotgroups and antibiotic resistance genes

\begin{tabular}{|c|c|c|c|}
\hline Primer name & Sequence & Size of product (bp) & Reference \\
\hline$\overline{\mathrm{O} 26-\mathrm{F}}$ & (F) CAGAATGGTTATGCTACTGT & 423 & {$[34]$} \\
\hline O26-R & (R) CTTACATTTGTTTTCGGCATC & & \\
\hline O103-F & (F) TTGGAGCGTTAACTGGACCT & 321 & [34] \\
\hline O103-R & (R) GCTCCCGAGCACGTATAAG & & \\
\hline O111-F & (F) TAGAGAAATTATCAAGTTAGTTCC & 406 & [34] \\
\hline O111-R & (R) ATAGTTATGAACATCTTGTTTAGC & & \\
\hline O145-F & (F) CCATCAACAGATTTAGGAGTGT & 609 & [34] \\
\hline O145-R & (R) TTCTACCGCGAATCTATC & & \\
\hline O157-F & (F) CGGACATCCATGTGATATGG & 259 & [34] \\
\hline O157-R & (R) TTGCCTATGTACAGCTAATCC & & \\
\hline $\mathrm{O} 45-\mathrm{F}$ & (F) CCGGGTTTCGATTTGTGAAGGTTG & 527 & {$[35]$} \\
\hline O45-R & (R) CACAACAGCCACTACTAGGCAGAA & & \\
\hline O91-F & (F) GCTGACCTTCATGATCTGTTGA & 291 & [36] \\
\hline O91-R & (R) TAATTAAACCCGTAGAATCGCTGC & & \\
\hline O113-F & (F) GGGTTAGATGGAGCGCTATTGAGA & 771 & [37] \\
\hline O113-R & (R) AGGTCACCCTCTGAATTATGGCAG & & \\
\hline O121-F & (F) TGGCTAGTGGCATTCTGATG & 322 & [38] \\
\hline O121-R & (R) TGATACTTTAGCCGCCCTTG & & \\
\hline O128-F & (F) GCTTTCTGCCGATATTTGGC & 289 & [39] \\
\hline O128-R & (R) CCGACGGACTGATGCCGGTGATT & & \\
\hline \multirow[t]{2}{*}{ aadAl } & (F) TATCCAGCTAAGCGCGAACT & 58 & [40] \\
\hline & (R) ATTTGCCGACTACCTTGGTC & & \\
\hline \multirow[t]{2}{*}{ tetA } & (F) GGTTCACTCGAACGACGTCA & 57 & [40] \\
\hline & (R) CTGTCCGACAAGTTGCATGA & & \\
\hline \multirow[t]{2}{*}{ tetB } & (F) CCTCAGCTTCTCAACGCGTG & 56 & [40] \\
\hline & (R) GCACCTTGCTGATGACTCTT & & \\
\hline \multirow[t]{2}{*}{ dfral } & (F) GGAGTGCCAAAGGTGAACAGC & 45 & [41] \\
\hline & (R) GAGGCGAAGTCTTGGGTAAAAAC & & \\
\hline \multirow[t]{2}{*}{ anr } & (F) GGGTATGGATATTATTGATAAAG & 50 & [20] \\
\hline & (R) CTAATCCGGCAGCACTATTTA & & \\
\hline \multirow[t]{2}{*}{$\operatorname{aac}(3)-I V$} & (F) CTTCAGGATGGCAAGTTGGT & 55 & [42] \\
\hline & (R) TCATCTCGTTCTCCGCTCAT & & \\
\hline \multirow[t]{2}{*}{ Sul1 } & (F) TTCGGCATTCTGAATCTCAC & 47 & [42] \\
\hline & (R) ATGATCTAACCCTCGGTCTC & & \\
\hline \multirow[t]{2}{*}{ blaSHV } & (F) TCGCCTGTGTATTATCTCCC & 52 & [42] \\
\hline & (R) CGCAGATAAATCACCACAATG & & \\
\hline \multirow[t]{2}{*}{ СITM } & (F) TGGCCAGAACTGACAGGCAAA & 47 & [42] \\
\hline & (R) TTTCTCCTGAACGTGGCTGGC & & \\
\hline \multirow[t]{2}{*}{ ereA } & (F) GCCGGTGCTCATGAACTTGAG & 52 & [42] \\
\hline & (R) CGACTCTATTCGATCAGAGGC & & \\
\hline \multirow[t]{2}{*}{ cat1 } & (F) AGTTGCTCAATGTACCTATAACC & 55 & [42] \\
\hline & (R) TTGTAATTCATTAAGCATTCTGCC & & \\
\hline \multirow[t]{2}{*}{$\mathrm{cm} / \mathrm{A}$} & (F) CCGCCACGGTGTTGTTGTTATC & 55 & [42] \\
\hline & (R) CACCTTGCCTGCCCATCATTAG & & \\
\hline
\end{tabular}


Table 2 Prevalence of STEC serogroups isolated from fermented dairy products in Iran

\begin{tabular}{|c|c|c|c|c|c|c|c|c|c|c|c|c|}
\hline Samples & $\begin{array}{c}\text { E. coli } \\
\text { positive (\%) }\end{array}$ & $\begin{array}{c}0157 \\
(\%)\end{array}$ & $\begin{array}{c}0145 \\
(\%)\end{array}$ & $\begin{array}{c}0128 \\
(\%)\end{array}$ & $\begin{array}{c}0121 \\
(\%)\end{array}$ & $\begin{array}{c}0113 \\
(\%)\end{array}$ & $\begin{array}{c}0111 \\
(\%)\end{array}$ & $\begin{array}{c}0103 \\
(\%)\end{array}$ & $\begin{array}{l}091 \\
(\%)\end{array}$ & $\begin{array}{l}\text { O45 } \\
(\%)\end{array}$ & $\begin{array}{l}\text { O26 } \\
(\%)\end{array}$ & $\begin{array}{c}\text { Non } \\
\text { detected (\%) } \\
\end{array}$ \\
\hline Yoghurt (200) & $20(10)$ & $5(25)$ & $1(5)$ & $2(10)$ & $1(5)$ & $1(5)$ & $1(5)$ & $1(5)$ & - & $1(5)$ & $3(15)$ & $4(20)$ \\
\hline Doogh (200) & $14(7)$ & $3(21.42)$ & $1(7.14)$ & $1(7.14)$ & - & $1(7.14)$ & $1(7.14)$ & $1(7.14)$ & $1(7.14)$ & - & $2(14.28)$ & $3(21.42)$ \\
\hline Kashk (200) & $16(8)$ & $5(31.25)$ & $1(6.25)$ & $1(6.25)$ & $1(6.25)$ & $1(6.25)$ & $1(6.25)$ & $1(6.25)$ & $1(6.25)$ & $1(6.25)$ & $1(6.25)$ & $2(12.5)$ \\
\hline Total (600) & $50(8.33)$ & $13(26)$ & $3(6)$ & $4(8)$ & $2(4)$ & $3(6)$ & $3(6)$ & $3(6)$ & $2(4)$ & $2(4)$ & $6(12)$ & $9(18)$ \\
\hline
\end{tabular}

eaeA, cdtB, papa, sfaS, fyuA, iutA, traT, and hlyA were employed as previously described [29-33].

To detect serogroups and antibiotic resistance genes in the E. coli isolates, several PCR assays were used. The primer sequences are summarized in Table 1. A DNA thermo-cycler (Eppendorf Mastercycler, Eppendorf-NethelHinz GmbH, Hamburg, Germany) was used in all PCR reactions. The amplified DNA products were electrophoresed on $2 \%$ agarose gels at $90 \mathrm{~V}$ for $3 \mathrm{~h}$ using $1 \times \mathrm{TBE}(0.89 \mathrm{M}$ Tris borate, $0.02 \mathrm{M}$ EDTA, pH 8.3) as the running buffer, then stained with ethidium bromide $(10 \mathrm{mg} / \mathrm{ml})$. Gels were visualized using a UV gel documentation system (Uvitech, UK). DNAs of E. coli O157:K88ac:H19, CAPM 5933, O159: $\mathrm{H} 20$ and CAPM 6006 strains were used as positive controls and distilled water was used as a negative control.

\section{Statistical analyses}

The data were analyzed using SPSS software (Version 17. SPSS Inc, United States) to find any significant correlation between incidences of virulence factors, serogroups and antibiotics resistance properties of $E$. coli strains isolated from dairy products. Statistical significance was regarded at a $P$ value $<0.05$.

\section{Results}

All of the dairy samples were tested using culture and PCR techniques. Distribution of E. coli strains in yoghurt, doogh and kashk is shown in Table 2. From 600 dairy samples, 50 (8.33\%) were positive for E. coli. We found that yoghurt were the most commonly contaminated dairy (10\%). We also found that O157 (26\%) and O26 (12\%) were the most commonly detected STEC O-serogroups among dairy samples. Distribution of putative virulence genes among $E$. coli strains isolated from dairy samples is shown in Table 3. Stx1 (44\%) had the highest incidence, followed by eae (36\%), papA (32\%) and stx2 (30\%). The Attaching and Effacing E. coli (AEEC) subtype was most commonly detected subtype (Table 4). All of the EHEC strains of our study harbored all of the stx1, eae and ehly genes (Table 4).

Dairy samples of the present study had the $\mathrm{pH}$ range of 4-6.1. The distribution of antimicrobial resistance genes within the STEC serogroups isolated from dairy samples is shown in Table 5. Genes that encode resistance to tetracycline, tetracycline, cephalothin, ampicillin and gentamicin antibiotics, i.e., tetA (76\%), tetB (70\%), blaSHV (38\%), CITM (36\%) and aac (3)-IV (32\%) were the most common antibiotic resistance genes in STEC serogroups isolated from dairy samples. Antimicrobial resistance pattern in the STEC serogroup isolates from the dairy samples is shown in Table 6. STEC strains exhibited the highest level of resistance to tetracycline (84\%), followed by penicillin (46\%), cephalothin (42\%), ampicillin (38\%) and streptomycin (36\%). We found that $50 \%$ of tested strains were resistant to more than one antibiotic.

\section{Discussion}

Our work has identified the high levels of contamination in yoghurt, doogh and kashk with E. coli strains. The distribution of $E$. coli strains in yoghurt, doogh and kashk were $10 \%, 7 \%$ and $8 \%$, respectively. There were significant differences $(P<0.05)$ in the incidence of $E$. coli strains between the yoghurt and doogh. Of the studies that have been conducted in this field [2,43-48], several have shown a low distribution of $E$. coli strains in yoghurt [45-48]. However, Rahimi et al. (2011) [47] failed to detection E. coli strains in yogurt. Unfortunately, there were no published data on the presence of E. coli strains in kashk and doogh.

One possible explanation for the low prevalence of E. coli strains in yoghurt, doogh and kashk is that all of

Table 3 Distribution of virulence genes in STEC strains isolated from fermented dairy products in Iran

\begin{tabular}{|c|c|c|c|c|c|c|c|c|c|c|c|c|}
\hline \multirow[t]{2}{*}{ Positive samples } & \multicolumn{12}{|c|}{ Virulence genes } \\
\hline & stx 1 & stx2 & eae & ehly & cnf1 & cnf2 & iutA & $c d t B$ & pap $A$ & $\operatorname{tra} T$ & sfas & fyu $A$ \\
\hline Yoghurt (20) & 12 & 8 & 9 & 6 & 6 & 4 & 2 & 3 & 7 & 5 & 2 & 3 \\
\hline Doogh (14) & 4 & 3 & 3 & 4 & 1 & 1 & 1 & 1 & 3 & 2 & 1 & - \\
\hline Kashk (16) & 6 & 4 & 6 & 4 & 2 & 3 & 2 & 1 & 6 & 3 & 1 & - \\
\hline Total (50) & $22(44)$ & $15(30)$ & $18(36)$ & $14(28)$ & $9(18)$ & $8(16)$ & $5(10)$ & $5(10)$ & $16(32)$ & $10(20)$ & $4(8)$ & $3(6)$ \\
\hline
\end{tabular}


Table 4 Distribution of virulence genes STEC seorgoups isolated from fermented dairy products in Iran

\begin{tabular}{lccc}
\hline Serotype & & $\begin{array}{c}\text { No. positive } \\
\text { samples (\%) }\end{array}$ & Virulence gene (\%) \\
\hline Non STEC & & $6(12)$ & - \\
STEC (88\%) & EHEC & $13(26)$ & stx1, eae, ehly: $13(100)$ \\
& AEEC & $31(62)$ & stx1: $22(70.96)$ stx2: 15 \\
& & $(48.38)$ eae: $18(58.06)$ \\
& & & stx1, eae: $14(45.16)$ stx2, eae: \\
& & & $10(32.25)$ stx1, stx2, eae: 7 (22.58) \\
& & &
\end{tabular}

these dairy samples are fermented. In addition, acidic $\mathrm{pH}$ and high temperature during their process cause to low distribution of $E$. coli strains. Therefore, majority of contamination rates in the studied dairy samples are occurred due to the cross contamination. In keeping with this, adequate heat and time were not performed in the traditionally production of dairy. Also, native people have no access to healthy water in many sites of Iran. High potential of polluted water in dairy contamination has been reported previously [49].

The high incidence of O157 (26\%) and O26 (12\%) serogroups in dairy products of our study have been also reported previously by Momtaz et al. (2012) [2], Caro et al. (2006) [50], Madic et al. (2011) [51] and Pradel et al. (2008) [52]. It seems that majority of STEC strains isolated from dairy samples harbored $\mathrm{O} 157$ and O26 serogroups. We found statistically significant $(P<0.05)$ differences between the incidence of O157 and O26 with other detected STEC serogroups. The most commonly detected serogroups in the study of Njage et al. (2012) [53] were O157, O111 and O113. Momtaz et al. (2012) [2] reported that O157, O145, O128, O121, O113, O111, O103, O91, O45, and O26 serogroups were detected in 14 (13.72\%), 2 (1.96\%), 4 (3.92\%),
3 (2.94\%), 3 (2.94\%), 10 (9.8\%), 6 (5.88\%), 2 (1.96\%), 6 (5.88\%), and 18 (17.64\%) dairy samples, respectively.

Another important finding relates to the distributions of several bacterial virulence factors in the dairy products of our study. We found statistically significant $(P<0.05)$ differences between the incidence of $s t x 1$ and $s t x 2$ genes and between the EHEC and AEEC subtypes $(P<0.05)$. The presence of multiple stx1,eaeA, and ehly genes was found in all of the EHEC strains (100\%). Also, the presence of multiple stx 1 and eaeA genes, stx 2 and $e a e A$ genes and finally stx 1 , stx2 and eaeA genes were found in $45.16 \%$, $32.25 \%$ and $22.58 \%$ of AEEC strains, respectively. Similar findings have been reported by Momtaz et al. (2012) [2], Mansouri-Najand and Khalili, (2007) [54] and Stephan et al. (2008) [55]. The same study found that out of the 77 E. coli isolates, $25(32.46 \%)$ could be classified as Shigatoxigenic based on PCR results (11, 3 and 11 isolates were positive for $s t x 1, s t x 2$, and both $s t x 1$ and $s t x 2$, respectively) [56]. Virpari et al. (2013) [57] showed that out of 80 E. coli isolates, 25 isolates (31.25\%) were positive for $s t x$ genes, of which $7(8.75 \%)$ isolates were positive for $s t x 1$ gene only, while $12(15.00 \%)$ isolates were positive for stx 2 gene and 5 (6.25\%) isolates were positive for both $s t x 1$ and $s t x 2,7$ isolates $(8.75 \%)$ were positive for eaeA gene and all isolates were negative for $r f b$ O157 gene.

We found statistically significant $(P<0.05)$ differences between the incidence of genes encode resistance to tetracycline and trimethoprim. There were no significant differences between the incidence of tet $A$ and tet $B$ and cat1 and cmlA genes. We found statistically significant $(P<0.05)$ differences between the incidence of antibiotic resistance against tetracycline and enrofloxacin and also penicillin and trimethoprim.

Bacterial resistance against chloramphenicol and nitrofurantoin $30 \%$ and $22 \%$, respectively. Chloramphenicol

Table 5 Distribution of antibiotic resistance genes in STEC serogroups isolated from fermented dairy products in Iran

\begin{tabular}{|c|c|c|c|c|c|c|c|c|c|c|c|c|}
\hline \multirow[t]{2}{*}{ STEC serotypes } & \multicolumn{12}{|c|}{ Antibiotic resistance genes } \\
\hline & aadA1 & tetA & tetB & dfrA1 & $q n r$ & aac (3)-IV & Sul1 & blaSHV & CITM & ereA & cat1 & $\mathrm{cmlA}$ \\
\hline O157 (13) & 4 & 9 & 11 & 1 & 1 & 5 & 2 & 6 & 6 & 4 & 3 & 3 \\
\hline $0145(3)$ & 2 & 3 & 2 & 1 & 1 & 1 & 1 & 3 & 2 & 1 & 1 & 1 \\
\hline $0128(4)$ & 1 & 4 & 4 & - & 1 & 2 & 1 & 1 & 1 & 1 & 1 & 1 \\
\hline $0121(2)$ & - & 2 & 2 & - & - & - & 1 & 2 & - & - & 1 & 1 \\
\hline $0113(3)$ & - & 2 & 1 & - & - & - & - & - & - & - & - & - \\
\hline $0111(3)$ & - & 1 & 1 & - & - & - & - & - & - & - & - & - \\
\hline 0103 (3) & - & 1 & 1 & - & - & - & - & - & - & - & - & - \\
\hline O91 (2) & - & 1 & - & - & - & - & - & - & - & - & - & - \\
\hline O45 (2) & - & 2 & 1 & - & - & - & - & - & 1 & - & - & - \\
\hline O26 (6) & 2 & 5 & 6 & 1 & 1 & 2 & 1 & 3 & 2 & 1 & 1 & 1 \\
\hline Non detected (9) & 6 & 8 & 6 & 2 & 2 & 6 & 3 & 4 & 6 & 2 & 4 & 5 \\
\hline Total (50) & $15(30)$ & $38(76)$ & $35(70)$ & $5(10)$ & $6(12)$ & $16(32)$ & $9(18)$ & 19 (38) & $18(36)$ & 9 (18) & $11(22)$ & $12(24)$ \\
\hline
\end{tabular}


Table 6 Antibiotic resistance pattern in STEC serogroups isolated from fermented dairy products in Iran

\begin{tabular}{|c|c|c|c|c|c|c|c|c|c|c|c|c|c|c|}
\hline $\begin{array}{l}\text { STES } \\
\text { serotypes }\end{array}$ & $\begin{array}{l}\text { P10* } \\
(\%)\end{array}$ & $\begin{array}{c}\text { TE30 } \\
(\%)\end{array}$ & $\begin{array}{l}\text { S10 } \\
(\%)\end{array}$ & $\begin{array}{l}\text { C30 } \\
\text { (\%) }\end{array}$ & $\begin{array}{l}\text { SXT } \\
(\%)\end{array}$ & $\begin{array}{c}\text { GM10 } \\
(\%)\end{array}$ & $\begin{array}{l}\text { E15 } \\
\text { (\%) }\end{array}$ & $\begin{array}{l}\text { NFX5 } \\
(\%)\end{array}$ & $\begin{array}{l}\text { L2 } \\
(\%)\end{array}$ & $\begin{array}{c}\text { CF30 } \\
(\%)\end{array}$ & $\begin{array}{l}\text { CIP5 } \\
\text { (\%) }\end{array}$ & $\begin{array}{c}\text { TMP5 } \\
\text { (\%) }\end{array}$ & $\begin{array}{c}\text { F/M300 } \\
\text { (\%) }\end{array}$ & $\begin{array}{c}\text { AM10 } \\
(\%)\end{array}$ \\
\hline O157 (13) & 5 & 10 & 5 & 3 & 3 & 4 & 3 & 2 & 5 & 5 & 2 & 2 & 3 & 4 \\
\hline 0145 (3) & 3 & 2 & 3 & 4 & 2 & 4 & - & 1 & 3 & 3 & 1 & 1 & 1 & 4 \\
\hline $0128(4)$ & 3 & 4 & 2 & 1 & - & 1 & 1 & - & 2 & 2 & 1 & - & 1 & 1 \\
\hline $0121(2)$ & 1 & 2 & 2 & 2 & 1 & 1 & 2 & 1 & 1 & 2 & - & - & 1 & 3 \\
\hline 0113 (3) & - & 1 & - & - & - & - & - & - & - & - & - & - & - & - \\
\hline 0111 (3) & 1 & 2 & - & - & - & 1 & - & - & - & - & - & - & - & - \\
\hline 0103 (3) & - & 1 & - & - & - & - & - & - & - & - & - & - & - & - \\
\hline O91 (2) & - & 1 & - & - & - & - & - & - & - & - & - & - & - & - \\
\hline O45 (2) & 1 & 2 & - & - & - & - & - & - & - & 1 & - & - & - & 1 \\
\hline O26 (6) & 3 & 4 & 2 & 2 & 1 & 2 & 1 & 1 & 3 & 2 & - & - & 2 & 1 \\
\hline $\begin{array}{l}\text { Non } \\
\text { detected (9) }\end{array}$ & 6 & 13 & 4 & 3 & 3 & 4 & 3 & 3 & 3 & 6 & 3 & 3 & 3 & 5 \\
\hline Total (50) & $23(46)$ & $42(84)$ & $18(36)$ & $15(30)$ & $10(20)$ & $17(34)$ & $10(20)$ & $8(16)$ & $17(34)$ & $21(42)$ & $7(14)$ & $6(12)$ & $11(22)$ & 19 (38) \\
\hline
\end{tabular}

*In this table P10 = penicillin ( $10 \mu \mathrm{g} /$ disk); TE30 = tetracycline $(30 \mu \mathrm{g} /$ disk); S10 = streptomycin $(10 \mu \mathrm{g} /$ disk); C30 = chloramphenicol (30 $\mu \mathrm{g} /$ disk); SXT = sulfamethoxazol $(25 \mu \mathrm{g} /$ disk); $G M 10=$ gentamycin $(10 \mu \mathrm{g} /$ disk); $E 15=$ erythromycin $(15 \mu \mathrm{g} / \mathrm{disk}) ; \mathrm{NFX} 5=$ enrofloxacin $(5 \mu \mathrm{g} / \mathrm{disk}) ; L 2=$ lincomycin $(2 \mu \mathrm{g} / \mathrm{disk}) ; C F 30=$ cephalothin $(30 \mu \mathrm{g} /$ disk); CIP5 = ciprofloxacin $(5 \mu \mathrm{g} /$ disk $) ; \mathrm{TMP} 5=$ trimethoprim $(5 \mu \mathrm{g} / \mathrm{disk}) ; \mathrm{F} / \mathrm{M} 300=$ nitrofurantoin $(300 \mu \mathrm{g} / \mathrm{disk}) ; A M 10=\mathrm{ampicillin}(10 \mathrm{u} / \mathrm{disk})$.

and nitrofurantoin are banned antibiotics and the high antibiotic resistances to these drugs detected in our study indicate that irregular and unauthorized use of them may have occurred in Iran. High bacterial resistances against chloramphenicol, nitrofurantoin, tetracycline, ampicillin and gentamicin have been reported previously $[2,4,19]$.

\section{Conclusions}

In conclusion, we identified a large number of serogroups, virulence factors and antibiotic resistance genes and resistance to more than one antibiotic in the E. coli strains isolated from yoghurt, doogh and kashk. Our data indicate that O157 and non-O157 STEC strains are predominant in Iranian dairy samples. Our data revealed that the O157 serogroup, the stx 1 , st $x 2$, eaeA and ehly putative virulence genes, the tet $A$, tetB, blaSHV and CITM antibiotic resistance genes, and resistance to tetracycline, penicillin, ampicillin and streptomycin were the most commonly detected characteristics of the E. coli strains isolated from yoghurt, doogh and kashk. Careful hygienic supervision on the processing and packaging of dairy products should be performed to reduce load of E. coli contamination. Adequate heat and time should also be performed in the traditionally production of dairy.

\section{Abbreviations}

E. coli: Escherichia coli; STEC: Shiga toxin producing Escherichia coli; EHEC: Enterohemolysin or Enterohaemorrhagic Escherichia coli; PCR: Polymerase chain reaction; Stx: Shiga Toxin; Eae: Intimin; Ehly: Hemolysin; Cnf1: Cytotoxic Necrotizing Factor; HUS: Hemolytic Uremic Syndrome; CDT: Cytolethal Distending Toxin; SPSS: Statistical Package for the Social Sciences.

\section{Competing interests}

The authors declare that they have no competing interests.

\section{Authors' contributions}

FSD carried out the molecular genetic studies, participated in the primers sequence alignment, design the study and writing and drafted the manuscript. FY and JM carried out the sampling and culture method. YV participated in the statistical analysis. All authors read and approved the final manuscript.

\section{Acknowledgements}

The authors would like to thank Prof. Ebrahim Rahimi, Prof. Ali Sharifzadeh and Prof. Hassan Momtaz at the Food Microbiology Research Center of the Islamic Azad University of Shahrekord for their important technical and clinical support.

Received: 24 October 2013 Accepted: 27 March 2014 Published: 7 April 2014

\section{References}

1. Ghorban Shiroodi S, Mohammadifar MA, Ghorbani Gorji E, Ezzatpanah H, Zohouri N: Influence of gum tragacanth on the physicochemical and rheological properties of kashk. J Dairy Res 2012, 79:93-101.

2. Walsh C, Duffy G, O'Mahony R, Fanning S, Blair IS, McDowell DA: Virulence markers of Escherichia coli strains isolated from traditional cheeses made from unpasteurised sheep milk in Slovakia. Food Control 2006, 17:393-396.

3. Momtaz H, Farzan R, Rahimi E, Safarpoor Dehkordi F, Souod N: Molecular characterization of Shiga toxin-producing Escherichia coli isolated from ruminant and Donkey raw milk samples and traditional dairy products in Iran. ScientificWorld J 2012, 2012:1-13.

4. Solomakos N, Govaris A, Angelidis AS, Pournaras S, Burriel AR, Kritas SK, Papageorgiou DK: Occurrence, virulence genes and antibiotic resistance of Escherichia coli 0157 isolated from raw bovine, caprine and ovine milk in Greece. Food Microbiol 2009, 26:865-871.

5. Thorpe CM: Shiga toxin-producing Escherichia coli infection. Clin Infect Dis 2004, 38:1298-1303.

6. Karch H, Tarr PI, Bielaszewska M: Enterohaemorrhagic Escherichia coli in human medicine. Int J Med Microbiol 2005, 295:405-418.

7. Wong CS, Jelacic S, Habeeb RL, Watkins SL, Tarr PI: The risk of the hemolytic-uremic syndrome after antibiotic treatment of Escherichia coli 0157:H7 infections. N Engl J Med 2000, 342:1930-1936. 
8. Tarr PI, Gordon CA, Chandler WL: Shiga-toxin-producing Escherichia coli and haemolytic uraemic syndrome. Lancet 2005, 365:1073-1086.

9. Bielaszewska M, Friedrich AW, Aldick T, Schürk-Bulgrin R, Karch H: Shiga toxin activatable by intestinal mucus in Escherichia coli isolated from humans: predictor for a severe clinical outcome. Clin Infect Dis 2006, 43:1160-1167.

10. Gerber A, Karch H, Allerberger F, Verweyen HM, Zimmerhackl LB: Clinical course and the role of shiga toxin-producing Escherichia coli infection in the hemolytic-uremic syndrome in pediatric patients, 1997-2000, in Germany and Austria: a prospective study. I Infect Dis 2002, 186:493-500

11. Bielaszewska M, Karch H: Consequences of enterohaemorrhagic Escherichia coli infection for the vascular endothelium. Thromb Haemost 2005, 94:312-318.

12. Law D: Virulence factors of Escherichia coli 0157 and other Shiga toxin-producing E. coli. J Appl Microbiol 2000, 88:729-745.

13. Peres SY, Marche's O, Daigle F, Nougayre'de JP, He'rault F, Tasca C, De Rycke J, Oswald E: A new cytolethal distending toxin (CDT) from Escherichia coli producing CNF2 blocks HeLa cell division in G2/M phase. Mol Microbiol 1997, 24:1095-1107.

14. De Rycke J, Oswald E: Cytolethal distending toxin (CDT): a bacterial weapon to control host cell proliferation? FEMS Microbiol Lett 2001, 203:141-148.

15. Schmidt H, Beutin L, Karch H: Molecular analysis of the plasmid-encoded hemolysin of Escherichia coli 0157:H7 strain EDL 933. Infect Immun 1995, 63:1055-1061

16. Käppeli U, Hächler H, Giezendanner N, Beutin L, Stephan R: Human infections with non-0157 Shiga toxin-producing Escherichia coli, Switzerland, 2000-2009. Emerg Infect Dis 2011, 17:180-185.

17. Erickson MC, Doyle MP: Food as a vehicle for transmission of Shiga toxin-producing Escherichia coli. J Food Protect 2007, 70:2426-2449.

18. Mora A, Blanco JE, Blanco M, Alonso MP, Dhabi G, Echeita A, González EA, Bernárdez Ml, Blanco J: Antimicrobial resistance of Shiga toxin (verotoxin)-producing Escherichia coli 0157:H7 and non-0157 strains isolated from humans, cattle, sheep and food in Spain. Res Microbiol 2005, 156:793-806.

19. Schroeder CM, Meng J, Zhao S, DebRoy C, Torcolini J, Zhao C, McDermott PF, Wagner DD, Walker RD, White DG: Antimicrobial resistance of Escherichia coli O26, 0103, 0111, 0128, and 0145 from animals and humans. Emerg Infect Dis 2002, 8:1409-1414.

20. Mammeri H, Van De Loo M, Poirel L, Martinez-Martinez L, Nordmann P: Emergence of plasmid-mediated quinolone resistance in Escherichia coli in Europe. Antimicrob Agents Chemother 2005, 49:71-76.

21. Cortés P, Blanc V, Mora A, Dahbi G, Blanco JE, Blanco M, López C, Andreu A, Navarro F, Alonso MP, Bou G, Blanco J, Llagostera M: Isolation and characterization of potentially pathogenic antimicrobial-resistant Escherichia coli strains from chicken and pig farms in Spain. Appl Environ Microbiol 2010, 76:2799-2805.

22. Zali MR, Moez Ardalan K, Parcham Azad K, Nik-Kholgh B: Etiologies of acute diarrheal diseases in Iran. J Res Med Sci 2003, 7:346-356.

23. Rezaie Homami M, Salmanzadeh Ahrabi S, Moez Ardalan K, Habibi E, Edalatkhah H, Jafari F, Moez Ardalan S, Zolfagharian K, Moghaddam Golmohammadi A, Azimi Rad M: Epidemiology of bacterial-induced acute diarrhea in Varamin. Pejouhandeh Q Res J 2003, 8:467-474.

24. Jafari F, Hamidian M, Rezadehbashi M, Doyle M, Salmanzadeh-Ahrabi S, Derakhshan F, Reza Zali M: Prevalence and antimicrobial resistance of diarrheagenic Escherichia coli and Shigella species associated with acute diarrhea in Tehran, Iran. Can J Infect Dis Med Microbiol 2009, 20:e56-e62.

25. Brueggemann AB: Antibiotic resistance mechanisms among pediatric respiratory and enteric pathogens: a current update. Pediatr Infect Dis J 2006, 25:969-973.

26. Sabat G, Rose P, Hickey WJ, Harkin JM: Selective and sensitive method for PCR amplification of Escherichia coli 16S rRNA genes in soil. Appl Environ Microbiol 2000, 66:844-849.

27. Clinical and Laboratory Standards Institute (CLSI): Performance standards for antimicrobial susceptibility testing; twenty-second informational supplement. Wayne, Pa: M100-S21, CLS; 2012.

28. Reischl U, Youssef MT, Kilwinski J, Lehn N, Zhang WL, Karch H, Strockbine NA Real-time fluorescence PCR assays for detection and characterization of Shiga toxin, intimin, and enterohemolysin genes from Shiga toxin-producing Escherichia coli. I Clin Microbiol 2002, 40:2555-2565.
29. Brian MJ, Frosolono M, Murray BE, Miranda A, Lopez EL, Gomez HF, Cleary TG: Polymerase chain reaction for diagnosis of enterohemorrhagic Escherichia coli infection and hemolytic-uremic syndrome. J Clin Microbiol 1992, 30:1801-1806.

30. Heuvelink AE, van de Kar NC, Meis JF, Monnens LA, Melchers WJ: Characterization of verocytotoxin-producing Escherichia coli 0157 isolates from patients with haemolytic uraemic syndrome in Western Europe. Epidemiol Infect 1995, 115:1-14.

31. Blanco M, Blanco JE, Blanco J, Alonso MP, Balsalobre C, Mouriño M, Madrid C, Juárez A: Polymerase chain reaction for detection of Escherichia coli strains producing cytotoxic necrotizing factor type 1 and 2 (CNF1 and CNF2). J Microbiol Method 1996, 26:95-101.

32. Johnson JR, Stell AL: Extended virulence genotypes of Escherichia coli strains from patients with urosepsis in relation to phylogeny and host compromise. The J Infect Dis 2000, 181:261-272.

33. Idress M, Mussarat U, Badshah Y, Qamar R, Bokhari H: Virulence factors profile of drug-resistant Escherichia coli isolates from urinary tract infections in Punjab, Pakistan. Eur J Clinl Microbiol Infect Dis 2010, 29:1533-1537.

34. Possé B, De Zutter L, Heyndrickx M, Herman L: Metabolic and genetic profiling of clinical 0157 and non-0157 Shiga-toxin-producing Escherichia coli. Res Microbiol 2007, 158:591-599.

35. DebRoy C, Fratamico PM, Roberts E, Davis MA, Liu Y: Development of PCR assays targeting genes in $\mathrm{O}$-antigen gene clusters for detection and identification of Escherichia coli $\mathrm{O} 45$ and $\mathrm{O} 55$ serogroups. Appl Environ Microbiol 2005, 77:4919-4924

36. Perelle S, Dilasser F, Grout J, Fach P: Identification of the O-antigen biosynthesis genes of Escherichia coli 091 and development of a 091 PCR serotyping test. J App/Microbiol 2002, 93:758-764.

37. DebRoy C, Roberts E, Kundrat J, Davis MA, Briggs CE, Fratamico PM: Detection of Escherichia coli serogroups $\mathrm{O} 26$ and 0113 by PCR amplification of the wzx and wzy genes. Appl Environ Microbiol 2004, 2004 (70):1830-1832.

38. Fratamico PM, Briggs CE, Needle D, Chen CY, DebRoy C: Sequence of the Escherichia coli $0121 \mathrm{O}$-antigen gene cluster and detection of enterohemorrhagic E. coli 0121 by PCR amplification of the wzx and wzy genes. J Clin Microbiol 2003, 44:3379-3383.

39. Shao J, Li M, Jia Q, Lu Y, Wang PG: Sequence of Escherichia coli 0128 antigen biosynthesis cluster and functional identification of an alpha-1,2-fucosyltransferase. FEBS Lett 2003, 553:99-103.

40. Randall LP, Cooles SW, Osborn MK, Piddock LJ, Woodward MJ: Antibiotic resistance genes, integrons and multiple antibiotic resistance in thirty-five serotypes of Salmonella enterica isolated from humans and animals in the UK. J Antimicrob Chemother 2004, 53:208-216.

41. Toro CS, Farfán M, Contreras I, Flores O, Navarro N, Mora GC, Prado V: Genetic analysis of antibiotic-resistance determinants in multidrugresistant Shigella strains isolated from Chilean children. Epidemiol Infect 2005, 133:81-86.

42. Van TT, Chin J, Chapman T, Tran LT, Coloe PJ: Safety of raw meat and shellfish in Vietnam: an analysis of Escherichia coli isolations for antibiotic resistance and virulence genes. Int J Food Microbiol 2008, 124:217-223.

43. Singh J, Batish VK, Grover S: A molecular beacon-based duplex real-time polymerase chain reaction assay for simultaneous detection of Escherichia coli 0157:H7 and Listeria monocytogenes in milk and milk products. Foodborne Pathog Dis 2009, 6:1195-1201.

44. Coia JE, Johnston Y, Steers NJ, Hanson MF: A survey of the prevalence of Escherichia coli 0157 in raw meats, raw cow's milk and raw-milk cheeses in south-east Scotland. Int J Food Microbio/ 2001, 66:63-69.

45. Shekarchian Chaleshtori S, Jazayeri A: Detection and antimicrobial resistance of Escherichia coli $\mathrm{O} 157$ isolated from traditional cheese, ice cream and yoghurt in Iran. Tehran Res J Dairy Sci 2011, 5:9-14.

46. Adetunji VO, Arigbede Ml: Occurrence of E. coli O157:H7 and Listeria monocytogenes and Identification of Hazard Analysis Critical Control Points (HACCPs) in Production Operations of a Typical Tropic Cheese 'Wara' and Yoghurt. Pak J Nut 2011, 10:796-804.

47. Rahimi E, Shekarchian Chaleshtori S, Parsaei P: Prevalence and antimicrobial resistance of Escherichia coli 0157 isolated from traditional cheese, ice cream and yoghurt in Iran. Afr J Microbiol Res 2011, 5:3706-3710.

48. Govaris A, Koidis P, Papatheodorou K: Behaviour of Escherichia coli 0157 H7 in sour milk, cows' milk yogurt and ewes' milk yogurt. J Dairy Res 2002, 69:655-660. 
49. Zhu P, Shelton DR, Karns JS, Sundaram A, Li S, Amstutz P, Tang CM: Detection of water-borne E. coli 0157 using the integrating waveguide biosensor. Biosens Bioelectron 2005, 21:678-683.

50. Caro I, Fernández-Barata VM, Alonso-Llamazares A, García-Armesto MR: Detection, occurrence and characterization of Escherichia coli 0157:H7 from raw ewe's milk in Spain. J Food Prot 2006, 69:920-924.

51. Madic J, Vingadassalon N, de Garam CP, Marault M, Scheutz F, Brugère H, Jamet E, Auvray F: Detection of Shiga toxin-producing Escherichia coli serotypes $\mathrm{O} 26: \mathrm{H} 11, \mathrm{O} 103: \mathrm{H} 2, \mathrm{O} 111: \mathrm{H} 8, \mathrm{O} 145: \mathrm{H} 28$, and $\mathrm{O} 157: \mathrm{H} 7$ in raw-milk cheeses by using multiplex real-time PCR. Appl Environ Microbiol 2011, 77:2035-2041.

52. Pradel N, Livrelli V, De Champs C, Palcoux JB, Reynaud A, Scheutz F, Sirot J, Joly B, Forestier C: Prevalence and characterization of Shiga toxin-producing Escherichia coli isolated from cattle, food, and children during a one-year prospective study in France. J Clin Microbiol 2000, 38:1023-1031.

53. Njage PMK, Jans C, Wangoh J, Lacroix C, Meile L: Detection, isolation and molecular characterisation of Shigatoxigenic 0157 and non-0157 Escherichia coli in raw and fermented camel milk. Afr J Microbiol Res 2012, 6:6031-6038.

54. Mansouri-Najand L, Khalili M: Detection of shiga-like toxigenic Escherichia coli from raw milk cheeses produced in Kerman-Iran. Vet Arch 2007, 77:515-522.

55. Stephan R, Schumacher S, Corti S, Krause G, Danuser J, Beutin L: Prevalence and characteristics of Shiga toxin-producing Escherichia coli in Swiss raw milk cheeses collected at producer level. J Dairy Sci 2008, 91:2561-2565.

56. D'Costa D, Bhosle SN, Dhuri RB, Doijad SP, Poharkar KV, Kalorey DR, Barbuddhe SB: Prevalence, serogroups, Shiga-toxin genes and pulsed field gel electrophoresis analyses of Escherichia coli isolated from bovine milk. Proc Nation Acad Sci, India Section B: Biol Sci 2013, 83:423-429.

57. Virpari PK, Nayak JB, Brahmbhatt MN, Thaker HC: Study on isolation, molecular detection of virulence gene and antibiotic sensitivity pattern of Escherichia coli isolated from milk and milk products. Vet World 2013, 6:541-545.

\section{doi:10.1186/1756-0500-7-217}

Cite this article as: Dehkordi et al:: Virulence factors, serogroups and antimicrobial resistance properties of Escherichia coli strains in fermented dairy products. BMC Research Notes 2014 7:217.

\section{Submit your next manuscript to BioMed Central and take full advantage of:}

- Convenient online submission

- Thorough peer review

- No space constraints or color figure charges

- Immediate publication on acceptance

- Inclusion in PubMed, CAS, Scopus and Google Scholar

- Research which is freely available for redistribution 